\title{
Seed treatment for improving wheat productivity under deficit irrigation conditions in arid environment
}

\author{
AbdAllah Mohamed El-Sanatawy ${ }^{1}$ and Abdel Tawab Metwally Zedan ${ }^{2}$ \\ ${ }^{1}$ Department of Agronomy, Faculty of Agriculture, Zagazig University, Egypt \\ ${ }^{2}$ Department of Agricultural Engineering, Faculty of Agriculture, Zagazig University, Egypt \\ [Received: January 19, 2020 Accepted: April 14, 2020 Published Online: April 16, 2020]
}

\begin{abstract}
Climate change and frequent drought events in arid regions present challenges for crop production and food security in many parts of the world. Objectives of the present research were to enhance wheat plant tolerance to water stress by applying regulated irrigation deficit scheme and treating seeds with drought-tolerant substances. A field experiment was carried out to study the impact of three irrigation levels (severe, moderate, and full irrigation) and three seed treatments [control, soaking in salicylic acid (SAA), and soaking in ascorbic acid (ASA)] on yield and its attributes and water use efficiency (WUE) of wheat. Moderate water stress significantly decreased total photosynthetic pigments, grain number/spike, spike number $/ \mathrm{m}^{2}$ and grain yield, however, amounts of water saving by this deficit irrigation rate suggested a feasible option for wheat production in water limited environments without unacceptable yield reduction. Treating seeds with SAA or ASA significantly increased total photosynthetic pigments, relative water content, recovery efficiency, grain number/spike and grain yield compared with untreated seeds. The efficacy of deficit irrigation was increased by treating seeds with SAA which was demonstrated by the increased grain number/spike, grain yield/ha and WUE compared to untreated seeds. These results suggest beneficial effects of drought-tolerant substances on enhancing plants' ability to mitigate the negative water stress impacts.
\end{abstract}

Keywords: Deficit irrigation, seed treatment, ascorbic acid, salicylic acid, WUE, recovery efficiency

\section{Introduction}

Globally, water availability has become an issue in recent years (Smakhtin et al. 2004). The Mediterranean region is in prospect to undergo increases in drought occurrences (Robredo et al. 2007). Hoerling et al. (2012) added that the Mediterranean region has suffered from the change of winter Mediterranean precipitation towards drier conditions which occurred due to region's sensitivity to regular global ocean warming; therefore, Mansour et al. (2017) pronounced that crop production was influenced critically by water limitations in arid and semi-arid regions, like Egypt. Bread wheat (Triticum aestivum L.) is the most prominent strategic crop in Egypt. Egyptian daily nutritional requirements depend on bread wheat for more than thousands of years. Wheat water requirements are expected to increase by $9 \%$ in North Egypt (the Nile Delta) and $18 \%$ in both Middle and Upper Egypt in 2040 (Ouda et al., 2016).

Irrigation with less than full crop water requirements termed as deficit irrigation (Attia et al. 2015), can be considered a chance to save water resources. Understanding the physiological, biochemical, and ecological obstructions related to drought stress is very important for better management (Fahad et al. 2017). Over-synthesis of reactive oxygen species occurs in plant cells due to water deficit stress (Zhu, 2000). The increased reactive oxygen species levels lead to various cellular mechanisms that result in damage and death of the cell (Ishikawa et al. 2009).

Many studies for the influence of water deficit on wheat grain yield and water use efficiency concluded that the grain yield could be largely maintained, while substantial reduction in irrigation volume could be used (Zhang and Oweis, 1999; Abdelraouf et al. 2013; Said, 2016; Said and Abd El-Moneem 2016).

Salicylic acid (SAA) is an endogenous growth regulator that belongs to the phenol group that is operative in different plant processes, particularly related to photosynthesis and water relations (Khan et al. 2003 and El-Shafey 2017). Salicylic acid plays an important role in enhancing plant resistance to biotic and abiotic stresses (El Tayeb and Ahmed, 2010; Ding and Ding, 2020).

Ascorbic acid (ASA) plays a vital role in regulating cell cycle and in several essential processes of plant growth and development (El-Shafey, 2017) and protecting plant cells against reactive oxygen species effects (Smirnoff, 2000).

\footnotetext{
*Email: mto252000@yahoo.com
} 
The influence of SAA and ASA, through seed treatment or foliar spraying, on wheat growth, productivity and WUE as well as water saving was investigated by (Amin et al. 2008; El Tayeb and Ahmed 2010; Farooq et al. 2013; Kotb and Elhamahmy 2013; El Sayed and Mujahed 2015; Said, 2016; Said and Abd El-Moneem 2016).

Objectives of the present research were (i) to enhance wheat plants tolerance to water stress by applying regulated deficit irrigation scheme and treating seeds with droughttolerant substances in arid environment, and (ii) to determine the best deficit irrigation rate that maximizes the marginal use of unit water applied without significant yield penalty.

\section{Materials and Methods}

A two-year field experiment was carried out at AbuHammad District, Sharkia Governorate, Egypt $\left(30^{\circ} 32^{\prime} \mathrm{N}\right.$ latitude, $31^{\circ} 36^{\prime} \mathrm{E}$ longitude and $74 \mathrm{~m}$ above sea level), during two successive winter seasons of (2016/2017) and (2017/2018) to study the effect of three irrigation levels and
(1) shows the soil physical and chemical analyses of the experimental site.

\section{Studied factors and Experimental design}

A strip plot design with three replicates was used. Horizontal strips were allocated to irrigation levels and the vertical strips were allocated for pre-sowing seed treatments. There were three irrigation levels; severe i.e. $50 \%$ of wheat evapotranspiration $\left(\mathrm{ET}_{\mathrm{c}}\right)(230 \mathrm{~mm})$, moderate i.e., $75 \% \mathrm{ET}_{\mathrm{c}}(345 \mathrm{~mm})$ and full i.e., $100 \% \mathrm{ET}_{\mathrm{c}}(460 \mathrm{~mm})$. Irrigation scheduling for all treatments was based on crop evapotranspiration $\left(\mathrm{ET}_{\mathrm{c}}\right)$ replacement according to the crop coefficient approach (Allen et al., 1998). $\mathrm{ET}_{\mathrm{c}}$ was calculated from the reference evapotranspiration $\mathrm{ET}_{0}$ and the $\mathrm{FAO}$ crop coefficients $\left(\mathrm{K}_{\mathrm{c}}\right)$ for wheat (Allen et al., 1998). $\mathrm{ET}_{\mathrm{o}}$ was calculated as follows:

$$
E T_{o}=\frac{0.408 \Delta\left(R_{n}-G\right)+\gamma \frac{900}{T+273} u_{2}\left(e_{s}-e_{a}\right)}{\Delta+\gamma\left(1+0.34 u_{2}\right)}
$$

Table 1: Physical and chemical analyses of the soil from experimental site $(30 \mathrm{~cm}$ depth)

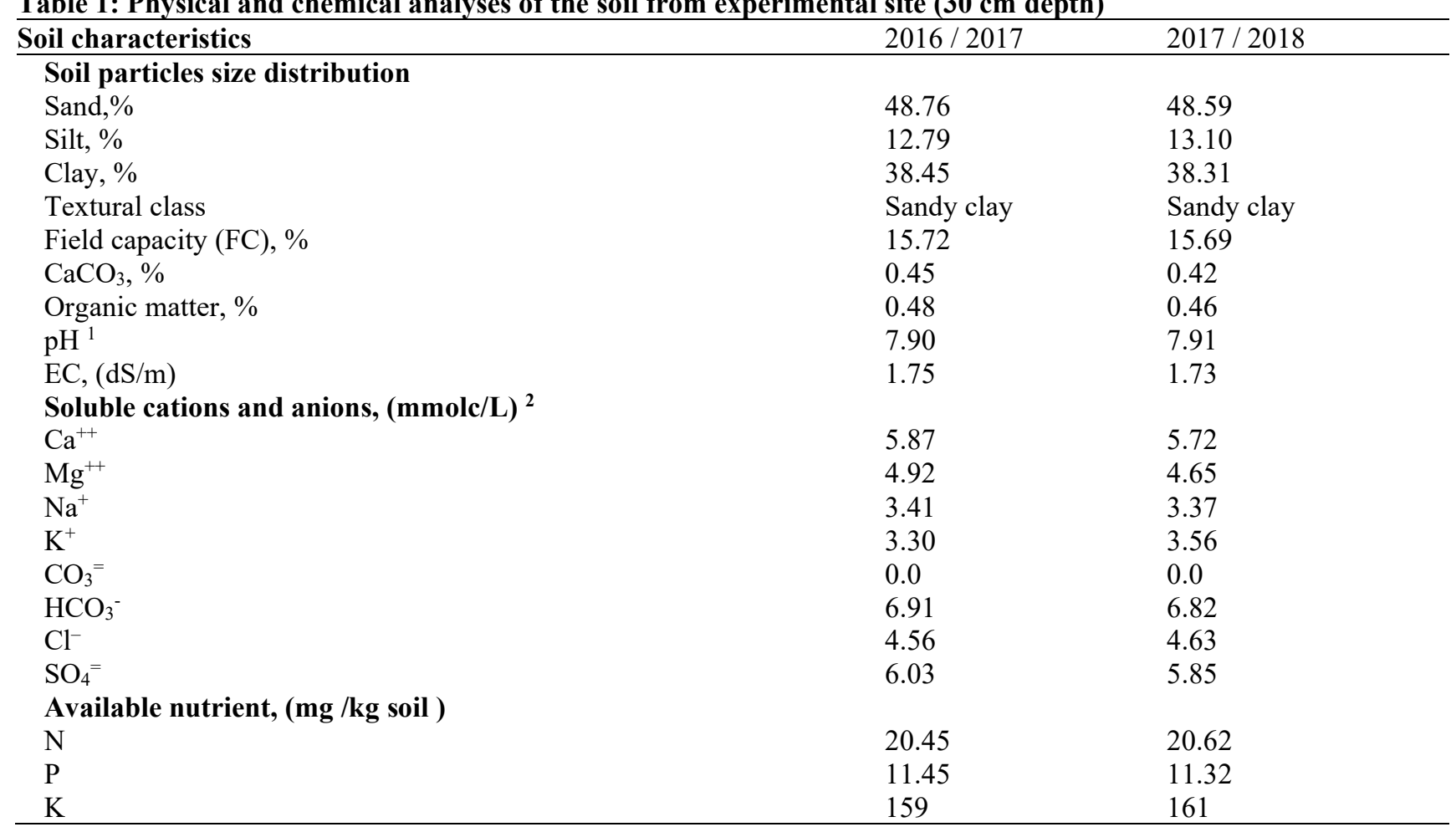

${ }^{1}$ Suspension of 1:2.5 soil : water
${ }^{2}$ Soil paste extract
Source: Soil Science Laboratory, Faculty of Agriculture, Zagazig University, Zagazig, Egypt

three seed treatments on grain yield, some of its attributes and water use efficiency of wheat cultivar "Shandaweel 1". The experimental field soil was sandy clay in texture. Table
Where:

$\mathrm{ET}_{\mathrm{o}}=$ the daily reference evapotranspiration $\left(\mathrm{mm} \mathrm{day}^{-1}\right)$, $\mathrm{Rn}=$ net radiation at the crop surface $\left(\mathrm{MJ} \mathrm{m}^{-2} \mathrm{day}^{-1}\right)$, 
$\mathrm{G}=$ soil heat flux density $\left(\mathrm{MJ} \mathrm{m}^{-2}\right.$ day $\left.^{-1}\right)$,

$\mathrm{T}=$ mean daily air temperature at $2 \mathrm{~m}$ height $\left({ }^{\circ} \mathrm{C}\right)$,

$\mathrm{U}_{2}=$ wind speed at $2 \mathrm{~m}$ height $\left(\mathrm{m} \mathrm{s}^{-1}\right)$,

$\mathrm{e}_{\mathrm{s}}=$ saturation vapor pressure $(\mathrm{kPa})$,

$\mathrm{e}_{\mathrm{a}}=$ actual vapor pressure $(\mathrm{kPa})$,

$\Delta=$ the slope of vapor pressure curve $\left(\mathrm{kPa}^{\circ} \mathrm{C}^{-1}\right)$,

$\gamma=$ the psychometric constant $\left(\mathrm{kPa}^{\circ} \mathrm{C}^{-1}\right)$.

Climatic factors during the experimental period were collected from automated weather station allocated at the experimental location and are shown in Table 2.

$\mathrm{ET}_{\mathrm{c}}$ was computed daily and irrigation water was added accordingly in five irrigation events distributed throughout the growing season to maintain the full water requirement for all treatments. Irrigation was terminated at the end of the growing season approximately one month before harvest shown in Table 3. A furrow irrigation system was used to deliver the targeted amount of irrigation water for each treatment and the discharge rate of the gate was estimated by using the formula of immersed orifice according to (James, 1988) as follows:

$$
\mathrm{Q}=0.61 \times 0.443 \times \mathrm{A} \sqrt{\mathrm{h}}
$$

Where:

$\mathrm{Q}=$ orifice discharge $\left(\mathrm{Lsec}^{-1}\right), \mathrm{A}=$ area of orifice $\left(\mathrm{cm}^{2}\right)$, $\mathrm{h}=$ effective water head over the orifice center $(\mathrm{m})$.

Horizontal strips separated by an alley of $3 \mathrm{~m}$ wide. Bunds of $30 \mathrm{~cm}$ height were constructed along each side of the horizontal strips and were covered by black plastic film inserted to a depth of $30 \mathrm{~cm}$ below the soil surface to prevent lateral movement of water.

The second experimental factor was the seed treatments that included three treatments of control (soaking in tap water for $8 \mathrm{~h}$ ), soaking in Salicylic acid (SAA) ( $2 \mathrm{mM}$ for $8 \mathrm{~h}$ ) and soaking in ascorbic acid (ASA) ( $2 \mathrm{mM}$ for $8 \mathrm{~h}$ ). Salicylic acid, also known as 2-hydroxybenzoic acid, is a colorless crystalline organic acid which functions as a plant hormone and the ascorbic acid, also called hexuronic acid, is a white solid which is known for its role as plant anti-stress substance.

\section{General agronomic practices}

Each plot area was $18 \mathrm{~m}^{2}(4 \times 4.5 \mathrm{~m})$. Wheat was preceded by maize in both seasons. Sowing took place on $15^{\text {th }}$ November in both seasons. Sowing was conducted in rows, $15 \mathrm{~cm}$ apart, using seeding rate of 400 seeds $\mathrm{m}^{-2}$. Harvest was done during the third week of April in both seasons. Calcium superphosphate $\left(15.5 \% \mathrm{P}_{2} \mathrm{O}_{5}\right)$, ammonium nitrate $(33.5 \% \mathrm{~N})$ and potassium sulphate $\left(50 \% \mathrm{~K}_{2} \mathrm{O}\right)$ were

Table 2: Average climatic data of the experimental location during the two growing seasons of (2016/2017 and 2017/2018)

\begin{tabular}{|c|c|c|c|c|c|c|c|c|c|}
\hline \multirow[t]{3}{*}{ Month } & \multirow[t]{2}{*}{ Date } & \multicolumn{4}{|l|}{$2016 / 2017$} & \multicolumn{4}{|l|}{$2017 / 2018$} \\
\hline & & Max. Temp. & Min. Temp. & Avg. RH & Precip. & Max. Temp. & Min. Temp. & Avg. RH & Precip. \\
\hline & Avg. From & $\mathrm{C}^{\mathrm{O}}$ & $\mathrm{C}^{\mathrm{o}}$ & $\%$ & $\mathrm{~mm}$ & $\mathrm{C}^{\mathrm{o}}$ & $\mathrm{C}^{\mathrm{O}}$ & $\%$ & $\mathrm{~mm}$ \\
\hline \multirow{3}{*}{$\begin{array}{l}\text { Nov. } \\
\text { Dec. }\end{array}$} & 15-31 Nov. & 22.9 & 15.3 & 58.9 & 0.51 & 24.0 & 15.1 & 48.4 & 1.02 \\
\hline & 1-15 Dec. & 22.1 & 13.1 & 60.5 & 4.06 & 22.1 & 13.1 & 57.2 & 0.25 \\
\hline & 16-31 Dec. & 21.9 & 14.4 & 56.7 & 0 & 21.9 & 14.4 & 50.7 & 0 \\
\hline \multirow[t]{2}{*}{ Jan. } & 1-15 Jan. & 17.7 & 9.1 & 50.4 & 0 & 20.1 & 12.1 & 55.6 & 0 \\
\hline & 16-31 Jan. & 18.8 & 10.4 & 55.2 & 0 & 18.3 & 11.6 & 55.7 & 5.33 \\
\hline \multirow[t]{2}{*}{ Feb. } & 1-15 Feb. & 19.5 & 10.6 & 55.6 & 0 & 24.5 & 13.7 & 53.8 & 0.25 \\
\hline & 16-28 Feb. & 20.5 & 10.2 & 56.6 & 2.03 & 22.4 & 14.2 & 49.2 & 13.21 \\
\hline \multirow[t]{2}{*}{ Mar. } & 1-15 Mar. & 22.8 & 14.5 & 51.1 & 0 & 27.1 & 16.5 & 49.4 & 0 \\
\hline & 16-31 Mar. & 24.8 & 15.2 & 48.7 & 0 & 28.5 & 16.3 & 42.6 & 2.03 \\
\hline \multirow[t]{2}{*}{ Apr. } & 1-15 Apr. & 26.0 & 16.1 & 52.8 & 4.31 & 28.4 & 17.0 & 48.5 & 1.02 \\
\hline & 16-30 Apr. & 29.7 & 17.6 & 42.9 & 0 & 29.8 & 19.1 & 43.4 & 5.08 \\
\hline
\end{tabular}

Table 3: Irrigation water amounts for the three irrigation levels throughout the growing seasons of wheat

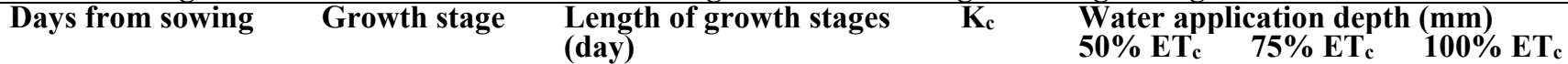

(I)

\begin{tabular}{|c|c|c|c|c|c|c|}
\hline & & & & $\left(I_{1}\right)$ & $\left(\mathbf{I}_{2}\right)$ & $\left(\mathbf{I}_{3}\right)$ \\
\hline $1-20$ & Initial & 20 & 0.70 & 18.8 & 28.2 & 37.6 \\
\hline $21-70$ & Development & 50 & 0.93 & 51.5 & 77.5 & 102.5 \\
\hline $71-130$ & Mid & 60 & 1.15 & 118.8 & 178.2 & 237.6 \\
\hline \multirow[t]{2}{*}{$131-160$} & Late & 30 & 0.50 & 40.8 & 61.5 & 81.9 \\
\hline & & & Total & 230 & 345 & 460 \\
\hline
\end{tabular}


applied at the rate of $215 \mathrm{~kg} \mathrm{~N} \mathrm{ha}^{-1}$, and $75 \mathrm{~kg} \mathrm{P}_{2} \mathrm{O}_{5} \mathrm{ha}^{-1}$ and $60 \mathrm{~kg} \mathrm{~K}_{2} \mathrm{O}$ ha $^{-1}$, respectively.

All other cultural practices were performed as recommended for wheat production in the study region.

\section{Recorded data}

At heading, 104 days after sowing (DAS), 10 guarded plants were selected randomly to measure flag leaf area using the formula (length $\times$ maximum width $\times 0.80$ ) according to Voldeng and Simpson (1967) and total photosynthetic pigments (SPAD value) using Minolta SPAD-502 chlorophyll meter. The total photosynthetic pigments content was recorded as a mean of 30 readings per plot.

During grain filling period (115 DAS) relative water content (RWC) and recovery efficiency at night (RE) were recorded. RWC was determined according to Barrs and Weatherley (1962) formula:

$$
\operatorname{RWC}(\%)=\frac{(\mathrm{FW}-\mathrm{DW})}{(\mathrm{TW}-\mathrm{DW})} \times 100
$$

Where: FW is the fresh weight of the leaf sample, DW is the dry weight of the leaf sample, TW is the weight of fresh leaf sample floated in distilled water for $8 \mathrm{~h}$.

$\mathrm{RE}$ is the change in RWC at night which represents the plant ability to compensate the loss of water occurring during the day, until $\psi$ plant would come close to equilibrium with the $\psi_{\text {soil }}$ at the end of the night. In other words, it is an adaptation mechanism to mitigate the negative impacts associated with water stress on plants. Consequently, RE (\%) is the difference between $\mathrm{RWC} \%$ at sunrise of a day (116 DAS) and the RWC\% at the sunset of the previous day
(115 DAS) as follows:

$$
\mathrm{RE}(\%)=\mathrm{RWC} \% \text { (sunrise) }-\mathrm{RWC} \% \text { (sunset) (4) }
$$

At harvest, ten spikes were randomly selected from each plot to estimate spike length $(\mathrm{cm})$, number of fertile spikelets spike $^{-1}$, grain number spike ${ }^{-1}$ and grain weight $\operatorname{spike}^{-1}(\mathrm{~g})$.

At harvest, all wheat plants of central square meter were harvested from each plot to estimate spikes number $\mathrm{m}^{-}$ ${ }^{2}$ and grain yield $\left(\mathrm{kg} \mathrm{ha}^{-1}\right)$ which was determined from the harvested area of each plot in terms of $\mathrm{kg} \mathrm{m}^{-2}$ and converted to $\mathrm{kg} \mathrm{ha}^{-1}$.

Water use efficiency (WUE) was calculated according to James (1988) and Bilalis et al., (2009) as follows:

$$
\text { WUE }=\frac{\text { Grain yield }}{\text { Total water applied }}
$$

Where: WUE is the water use efficiency $\left(\mathrm{kg} \mathrm{m}^{-3}\right)$, grain yield $\left(\mathrm{kg} \mathrm{ha}^{-1}\right)$ and the total water applied $\left(\mathrm{m}^{3} \mathrm{ha}^{-1}\right)$.

\section{Data analysis}

The experimental data of both seasons and their combined data were subjected to the analysis of variance according to the standard statistical procedures described by (Gomez and Gomez 1984) by using MSTAT-C statistical program version 2.1 (Mstat 1989). The combined analysis of variance of both trials was calculated after establishing Bartlett's homogeneity test (Steel et al., 1997), since the error variance of the individual seasons was homogeneous. The differences among treatments were compared using Duncan's multiple range test (Duncan 1955), where means

Table 4: Flag leaf area $\left(\mathrm{cm}^{2}\right)$, total photosynthetic pigments (SPAD value), RWC (\%) and RE (\%) of wheat as

\begin{tabular}{|c|c|c|c|c|c|c|c|c|c|c|c|c|}
\hline \multirow[t]{2}{*}{$\begin{array}{l}\text { Main effects } \\
\text { and interaction }\end{array}$} & \multicolumn{3}{|c|}{$\begin{array}{l}\text { Flag leaf area } \\
\left(\mathrm{cm}^{2}\right)\end{array}$} & \multicolumn{3}{|c|}{$\begin{array}{c}\text { Total photosynthetic } \\
\text { pigments (SPAD value) }\end{array}$} & \multicolumn{3}{|c|}{ RWC (\%) } & \multicolumn{3}{|c|}{ RE (\%) } \\
\hline & $\begin{array}{l}2016 / \\
2017\end{array}$ & $\begin{array}{l}2017 / \\
2018\end{array}$ & Com. & $\begin{array}{l}2016 / \\
2017\end{array}$ & $\begin{array}{l}2017 / \\
2018\end{array}$ & Com. & $\begin{array}{l}\text { 2016/ } \\
2017\end{array}$ & $\begin{array}{l}2017 / \\
2018\end{array}$ & Com. & $\begin{array}{l}\text { 2016/ } \\
2017\end{array}$ & $\begin{array}{l}2017 / \\
2018\end{array}$ & Com. \\
\hline Irrigation levels (I) $^{1}$ & & & & & & & & & & & & \\
\hline $50 \%$ ETc & 30.95 & 32.75 & $31.85 \mathrm{~b}$ & $43.62 b$ & $40.96 \mathrm{c}$ & $42.29 \mathrm{c}$ & 66.24 & $64.47 \mathrm{~b}$ & $65.35 \mathrm{~b}$ & 7.58 & 5.99 & 6.78 \\
\hline $75 \%$ ETc & 34.11 & 36.05 & $35.08 \mathrm{ab}$ & $49.28 \mathrm{a}$ & $47.82 \mathrm{~b}$ & $48.55 \mathrm{~b}$ & 72.85 & $71.93 a$ & $72.39 \mathrm{a}$ & 6.67 & 5.11 & 5.89 \\
\hline $100 \%$ ETc & 38.35 & 40.76 & $39.56 \mathrm{a}$ & $51.77 \mathrm{a}$ & $53.41 \mathrm{a}$ & $52.59 \mathrm{a}$ & 76.82 & $74.91 \mathrm{a}$ & $75.87 \mathrm{a}$ & 4.73 & 4.44 & 4.58 \\
\hline F. test ${ }^{2}$ & NS & NS & & * & & * & NS & & & NS & NS & NS \\
\hline Seed treatments (S) & & & & & & & & & & & & \\
\hline $\begin{array}{l}\text { Control } \\
\text { Soaking in SAA }\end{array}$ & 32.07 & $33.07 \mathrm{c}$ & $32.57 \mathrm{~b}$ & 47.04 & 46.21 & $46.62 b$ & 68.14 & $65.37 \mathrm{~b}$ & $66.75 \mathrm{~b}$ & $3.68 \mathrm{~b}$ & $3.32 b$ & $3.50 \mathrm{~b}$ \\
\hline Soaking in SAA & 34.84 & $36.13 b$ & $35.49 \mathrm{ab}$ & 49.13 & 48.03 & $48.58 \mathrm{a}$ & 74.63 & $74.66 \mathrm{a}$ & $74.64 a$ & $8.77 \mathrm{a}$ & $6.70 \mathrm{a}$ & $7.73 \mathrm{a}$ \\
\hline Soaking in ASA & 36.50 & $40.37 \mathrm{a}$ & $38.43 \mathrm{a}$ & 48.51 & 47.95 & $48.23 \mathrm{a}$ & 73.15 & $71.28 \mathrm{a}$ & $72.21 \mathrm{a}$ & $6.53 \mathrm{ab}$ & $5.52 \mathrm{ab}$ & $6.03 a$ \\
\hline F. test & NS & & & NS & NS & $*$ & NS & & & & & \\
\hline $\begin{array}{l}\text { Interaction } \\
\text { I x S }\end{array}$ & NS & $*$ & $*$ & * & * & * & * & * & $*$ & NS & NS & NS \\
\hline
\end{tabular}
affected by irrigation levels and seed treatments during (2016/2017) and (2017/2018) seasons and their combined data

${ }^{1}$ Least significant difference at the $95 \%$ confidence level was used to compare between means. Means of irrigation levels or seed treatments followed by the same letter are not significantly different. Columns that do not contain letters indicate no significant difference between treatments.

$2 *$ and NS indicate significance at 0.05 level of probability and non-significance of differences, respectively.

$50 \%$ ETc $(230 \mathrm{~mm}), 75 \%$ ETc $(345 \mathrm{~mm})$ and 100\% ETc $(460 \mathrm{~mm})$. 
Table 5: Flag leaf area $\left(\mathrm{cm}^{2}\right)$, total photosynthetic pigments (SPAD value) and $R W C \%$ of wheat as affected by the interaction between irrigation levels and seed treatments (combined data)

Seed treatments (S) $\quad$ Irrigation levels (I)

$50 \%$ ET $_{c} \quad 75 \%$ ET $_{c} \quad 100 \%$ ET $_{c}$ Flag leaf area $\left(\mathrm{cm}^{2}\right)$

\begin{tabular}{|c|c|c|c|}
\hline \multicolumn{4}{|c|}{ Flag leaf area $\left(\mathrm{cm}^{2}\right)$} \\
\hline & A & A & A \\
\hline \multirow{2}{*}{ Control } & $30.09 a$ & $34.45 \mathrm{a}$ & $33.18 b$ \\
\hline & B & B & A \\
\hline \multirow[t]{2}{*}{ Soaking in SAA } & $30.59 a$ & $33.76 a$ & $42.11 \mathrm{a}$ \\
\hline & B & $\mathrm{AB}$ & A \\
\hline Soaking in ASA & $34.88 \mathrm{a}$ & $37.03 \mathrm{a}$ & $43.39 \mathrm{a}$ \\
\hline
\end{tabular}

Total photosynthetic pigments (SPAD value)

\begin{tabular}{|c|c|c|c|}
\hline & $\mathrm{C}$ & B & A \\
\hline \multirow[t]{2}{*}{ Control } & $41.35 \mathrm{a}$ & $47.35 \mathrm{a}$ & $51.18 \mathrm{a}$ \\
\hline & $\mathrm{C}$ & B & A \\
\hline \multirow[t]{2}{*}{ Soaking in SAA } & $43.06 \mathrm{a}$ & $49.33 \mathrm{a}$ & $53.35 \mathrm{a}$ \\
\hline & $\mathrm{C}$ & B & A \\
\hline \multirow[t]{3}{*}{ Soaking in ASA } & $42.46 a$ & $48.98 \mathrm{a}$ & $53.25 \mathrm{a}$ \\
\hline & RWC\% & & \\
\hline & $\mathrm{B}$ & A & A \\
\hline \multirow[t]{2}{*}{ Control } & $58.04 b$ & $68.29 \mathrm{a}$ & $73.93 a$ \\
\hline & A & A & A \\
\hline \multirow[t]{2}{*}{ Soaking in SAA } & $72.38 \mathrm{a}$ & $74.72 \mathrm{a}$ & $76.82 \mathrm{a}$ \\
\hline & B & A & A \\
\hline Soaking in ASA & $65.64 \mathrm{ab}$ & $74.16 \mathrm{a}$ & $76.16 \mathrm{a}$ \\
\hline \multicolumn{4}{|c|}{$\begin{array}{l}\text { Least significant difference at the } 95 \% \text { confidence level was used to } \\
\text { compare means. } \\
\text { Capital and small letters were used to compare means in rows and columns, } \\
\text { respectively. }\end{array}$} \\
\hline
\end{tabular}

with different letters were statistically significant. In the interaction tables, capital and small letters were used to compare between means in rows and columns, respectively.

\section{Results}

Combined analysis results presented in Table (4) revealed that reducing irrigation water requirements from $100 \%$ to $75 \% \mathrm{ET}_{\mathrm{c}}$ was not accompanied by a significant decrease in flag leaf area, RWC (\%) and RE (\%), but the total photosynthetic pigments (SPAD value) was significantly decreased with reducing irrigation water level.

Treating seeds with ASA or SAA significantly increased total photosynthetic pigments, RWC and RE compared with the control. However, treating seeds with ASA significantly enlarged flag leaf area compared to the control, with no significant difference between treating seeds with ASA or SAA and between treating seeds with SAA and the control treatment.

The interaction between the two studied factors had a significant effect on flag leaf area, total photosynthetic pigments and RWC as shown in Table (5). Reducing irrigation water requirements from $100 \%$ to $75 \% \mathrm{ET}_{\mathrm{c}}$ significantly decreased total photosynthetic pigments, but it had no significant influence on RWC and flag leaf area, except flag leaf area produced from seeds treated with SAA. Treating seeds with SAA or ASA significantly enlarged flag leaf area under full irrigation conditions by about 26.91 and $30.77 \%$, respectively. Under severe water stress conditions, treating seeds with SAA significantly enhanced RWC compared to the control by about $24.71 \%$, with no significant

Table 6: Spike length (cm), number of fertile spikelets spike ${ }^{-1}$, grain number spike ${ }^{-1}$ and grain weight spike ${ }^{-1}$ (g) of wheat as affected by irrigation levels and seed treatments during (2016/2017) and (2017/2018) seasons and their combined data

\begin{tabular}{|c|c|c|c|c|c|c|c|c|c|c|c|c|}
\hline \multirow[t]{2}{*}{$\begin{array}{l}\text { Main effects } \\
\text { and interaction }\end{array}$} & \multicolumn{3}{|c|}{$\begin{array}{l}\text { Spike length } \\
(\mathrm{cm})\end{array}$} & \multicolumn{3}{|c|}{$\begin{array}{l}\text { Number of fertile } \\
\text { Spikelets/spike }\end{array}$} & \multicolumn{3}{|c|}{$\begin{array}{l}\text { Grain number } \\
\text { Spike }^{-1}\end{array}$} & \multicolumn{3}{|c|}{$\begin{array}{l}\text { Grain weight } \\
\text { Spike }^{-1}(\mathrm{~g})\end{array}$} \\
\hline & $\begin{array}{l}2016 / \\
2017\end{array}$ & $\begin{array}{l}2017 / \\
2018\end{array}$ & Com. & $\begin{array}{l}2016 / \\
2017\end{array}$ & $\begin{array}{l}2017 / \\
2018\end{array}$ & Com. & $\begin{array}{l}2016 / \\
2017\end{array}$ & $\begin{array}{l}2017 / \\
2018\end{array}$ & Com. & $\begin{array}{l}2016 / \\
2017\end{array}$ & $\begin{array}{l}2017 / \\
2018\end{array}$ & Com. \\
\hline Irrigation levels (I) $^{1}$ & & & & & & & & & & & & \\
\hline $50 \% \mathrm{ET}_{\mathrm{c}}$ & $9.84 b$ & $8.28 b$ & $9.06 \mathrm{~b}$ & 13.82 & $11.03 \mathrm{~b}$ & $12.42 \mathrm{~b}$ & $00.25 \mathrm{c}$ & $26.22 \mathrm{c}$ & $25.61 \mathrm{c}$ & $1.01 \mathrm{~b}$ & $1.03 \mathrm{c}$ & $1.02 \mathrm{~b}$ \\
\hline $75 \% \mathrm{ET}_{\mathrm{c}}$ & $12.69 \mathrm{a}$ & $10.68 \mathrm{a}$ & $11.68 \mathrm{a}$ & 16.93 & $15.28 \mathrm{a}$ & $16.11 \mathrm{ab}$ & $39.26 \mathrm{~b}$ & $40.73 \mathrm{~b}$ & $40.00 \mathrm{~b}$ & $1.63 \mathrm{a}$ & $1.63 \mathrm{~b}$ & $1.63 \mathrm{a}$ \\
\hline $100 \% \mathrm{ET}_{\mathrm{c}}$ & $11.51 \mathrm{ab}$ & $11.34 \mathrm{a}$ & $11.42 \mathrm{a}$ & 17.17 & $16.08 \mathrm{a}$ & $16.63 a$ & $47.16 \mathrm{a}$ & $45.08 \mathrm{a}$ & $46.12 \mathrm{a}$ & $1.68 \mathrm{a}$ & $1.81 \mathrm{a}$ & $1.74 \mathrm{a}$ \\
\hline F. test $^{2}$ & & & & $\mathrm{NS}$ & & & $*$ & & & $*$ & & \\
\hline Seed treatments (S) & & & & & & & & & & & & \\
\hline Control & 10.96 & 10.04 & 10.50 & $14.95 b$ & 14.04 & $14.50 \mathrm{~b}$ & $33.17 \mathrm{~b}$ & $34.06 \mathrm{~b}$ & $33.62 \mathrm{~b}$ & 1.36 & $1.36 \mathrm{~b}$ & $1.36 \mathrm{~b}$ \\
\hline Soaking in SAA & 11.28 & 10.28 & 10.78 & $17.10 \mathrm{a}$ & 14.70 & $15.90 \mathrm{a}$ & $39.32 \mathrm{a}$ & $39.11 \mathrm{a}$ & $39.22 \mathrm{a}$ & 1.41 & $1.58 \mathrm{a}$ & $1.49 \mathrm{ab}$ \\
\hline Soaking in ASA & 11.81 & 9.97 & 10.89 & $15.87 \mathrm{ab}$ & 13.66 & $14.77 b$ & $38.93 \mathrm{a}$ & $38.86 \mathrm{a}$ & $38.90 \mathrm{a}$ & 1.55 & $1.53 \mathrm{a}$ & $1.54 \mathrm{a}$ \\
\hline F. test & NS & NS & NS & & NS & & * & $*$ & $*$ & NS & $*$ & $*$ \\
\hline $\begin{array}{l}\text { Interaction } \\
\text { I } x \text { S }\end{array}$ & $*$ & $*$ & * & * & * & $*$ & $*$ & * & * & $*$ & $*$ & * \\
\hline
\end{tabular}

${ }^{1}$ Least significant difference at the $95 \%$ confidence level was used to compare means. Means of irrigation levels or seed treatments followed by the same letter are not significantly different. Columns that do not contain letters indicate no significance difference between treatments.

$2 *$ and NS indicate significance at 0.05 level of probability and non-significance of differences, respectively.

$50 \%$ ETc $(230 \mathrm{~mm}), 75 \%$ ETc $(345 \mathrm{~mm})$ and $100 \%$ ETc $(460 \mathrm{~mm})$. 
differences between treating seeds with SAA or ASA and between treating seeds with ASA and the control.

For the yield attributes, combined analysis in Table (6) showed that reducing irrigation water level from $100 \%$ to $75 \% \mathrm{ET}_{\mathrm{c}}$ produced at par statistical values for spike length, number of fertile spikelets spike ${ }^{-1}$ and grain weight spike ${ }^{-1}$, but grain number spike ${ }^{-1}$ was significantly decreased with reducing irrigation water level by about $13.27 \%$.

Spike length did not significantly change under seed treatments. Treating seeds with SAA or ASA produced at

Table 7: Spike length (cm), number of fertile spikelets spike ${ }^{-1}$, grain number spike ${ }^{-1}$ and grain weight spike ${ }^{-1}(\mathrm{~g})$ of wheat as affected by the interaction between irrigation levels and seed treatments (combined data)

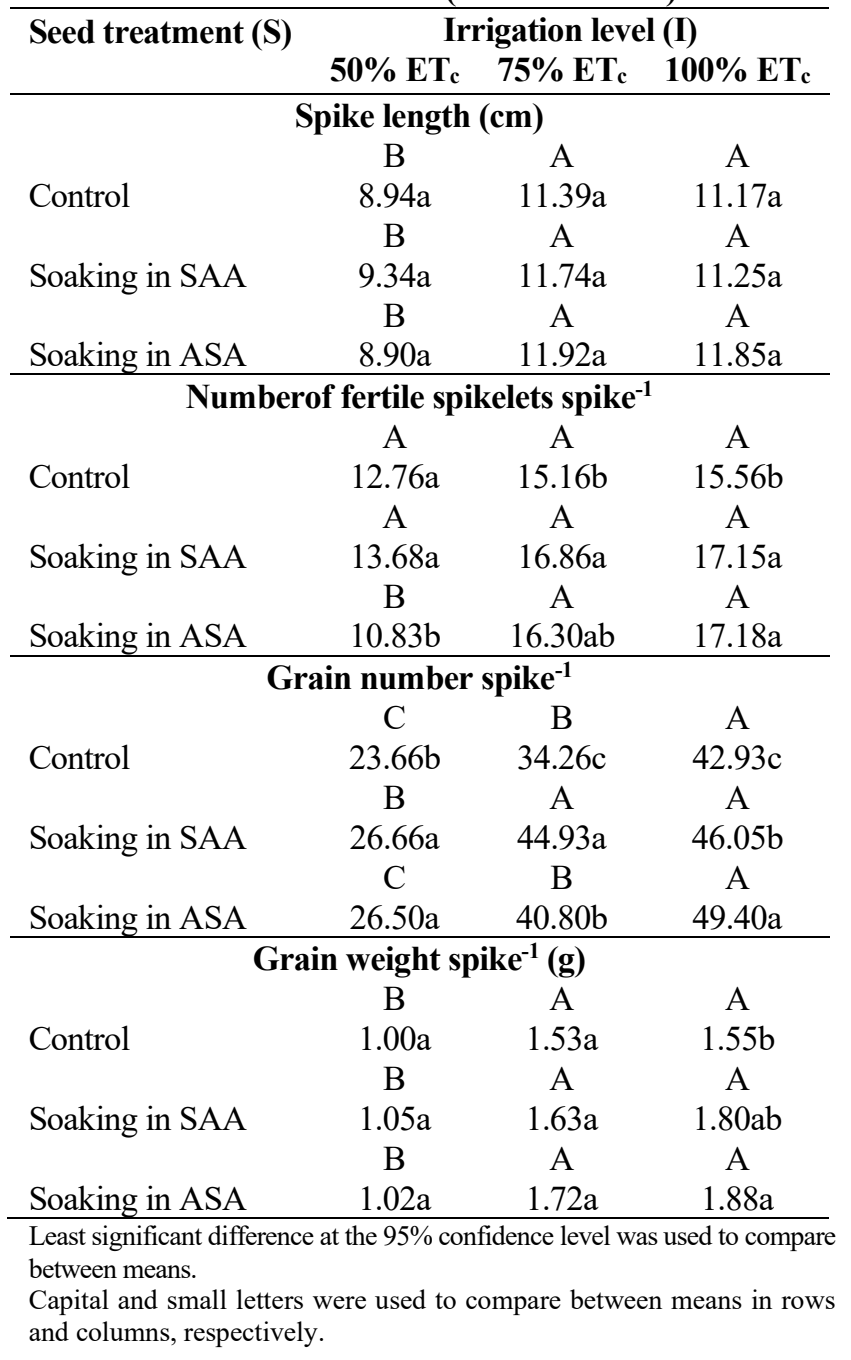

par significant increase in grain number spike ${ }^{-1}$ and grain weight spike $^{-1}$. Treating seeds with SAA significantly increased the number of fertile spikelets spike ${ }^{-1}$.

A significant interaction between the two studied factors was observed in both seasons and their combined analysis for the aforementioned traits. Results illustrated in Table (7) indicated that the reduction in irrigation water requirements from $100 \%$ to $75 \% \mathrm{ET}_{\mathrm{c}}$ had no significant impact on spike length, number of fertile spikelets spike ${ }^{-1}$ and grain weight spike $^{-1}$; however, it significantly decreased grain number spike ${ }^{-1}$ when the seeds were treated with water or ASA. Treating seeds with ASA produced the lowest significant number of fertile spikelets spike $^{-1}$ under severe water stress conditions. Treating seeds with SAA or ASA significantly increased the number of fertile spikelets spike ${ }^{-1}$ under normal irrigation conditions. Under any irrigation level, treating seeds with SAA or ASA significantly increased grain number spike-1 compared with the control. Regarding grain weight spike ${ }^{-1}$, there were no significant differences among seed treatments in grain weight spike ${ }^{-1}$ under severe and moderate water stress conditions. Under normal irrigation conditions seed soaking in ASA significantly increased grain weight spike ${ }^{-1}$ compared to soaking in water, with no significant difference between treating seeds with ASA or SAA and between treating seeds with SAA and the control.

Table 8 showed that, reducing irrigation water level from $100 \%$ to $75 \%$ or $50 \% \mathrm{ET}_{\mathrm{c}}$ significantly decreased spike number $\mathrm{m}^{-2}$, grain yield ha ${ }^{-1}$ by about $5.17 \%$ and $9.41 \%$ for spike number $\mathrm{m}^{-2}$ as well as $23.01 \%$ and $49.23 \%$ for grain yield $\mathrm{ha}^{-1}$, respectively. The WUE was not significantly affected by reducing irrigation water level from $100 \%$ to $75 \% \mathrm{ET}_{\mathrm{c}}$.

Seed treatments had a negligible influence on spike number $\mathrm{m}^{-2}$. Treating seeds with SAA or ASA significantly produced high grain yield ha $^{-1}$ compared with the control, with no significant differences between treating seeds with SAA or ASA. Treating seeds with SAA significantly increased WUE compared with the two others seed treatments.

The interaction between the two studied factors had a significant impact on the aforementioned traits in the combined analysis as presented in Table (9). In most cases, reducing irrigation water levels significantly decreased spike number $\mathrm{m}^{-2}$ and grain yield $\mathrm{ha}^{-1}$. WUE was not affected significantly by reducing irrigation level under any seed treatment. 
Table 8: Spike number $\mathrm{m}^{-2}$, grain yield $\left(\mathrm{kg} \mathrm{ha}^{-1}\right)$ and WUE $\left(\mathrm{kg} \mathrm{m}^{-3}\right)$ of wheat as affected by irrigation levels and seed treatments during (2016/2017) and (2017/2018) seasons and their combined data

\begin{tabular}{|c|c|c|c|c|c|c|c|c|c|}
\hline \multirow{2}{*}{$\begin{array}{l}\text { Main effects } \\
\text { and interaction }\end{array}$} & \multicolumn{3}{|c|}{ Spike numberm $^{-2}$} & \multicolumn{3}{|c|}{$\begin{array}{l}\text { Grain yield } \\
\left(\mathrm{kgha}^{-1}\right)\end{array}$} & \multicolumn{3}{|c|}{ WUE $\left(\mathrm{kg} \mathrm{m}^{-3}\right)$} \\
\hline & $2016 / 2017$ & $2017 / 2018$ & Com. & $2016 / 2017$ & $2017 / 2018$ & Com. & $2016 / 2017$ & $2017 / 2018$ & Com. \\
\hline \multicolumn{10}{|l|}{${\text { Irrigation levels }(I)^{1}}^{1}$} \\
\hline $50 \% \mathrm{ET}_{\mathrm{c}}$ & $452.67 b$ & $447.56 \mathrm{c}$ & $450.11 \mathrm{c}$ & $4054.3 \mathrm{c}$ & $4043.5 \mathrm{c}$ & $4048.9 \mathrm{c}$ & 2.13 & 2.11 & 2.12 \\
\hline $75 \% \mathrm{ET}_{\mathrm{c}}$ & $481.63 \mathrm{ab}$ & $460.67 \mathrm{~b}$ & $471.15 \mathrm{~b}$ & $5945.8 b$ & $6334.5 b$ & $6140.1 \mathrm{~b}$ & 2.08 & 2.20 & 2.14 \\
\hline $100 \% \mathrm{ET}_{\mathrm{c}}$ & $501.31 \mathrm{a}$ & $492.41 \mathrm{a}$ & $496.86 \mathrm{a}$ & $8118.2 \mathrm{a}$ & $7832.8 \mathrm{a}$ & $7975.5 a$ & 2.13 & 2.05 & 2.09 \\
\hline F. test ${ }^{2}$ & & & & & & & NS & NS & NS \\
\hline \multicolumn{10}{|l|}{ Seed treatments $(S)$} \\
\hline Control & 472.90 & 467.38 & 470.14 & $5283.5 \mathrm{c}$ & 5456.9 & $5370.2 b$ & $1.84 \mathrm{c}$ & $1.88 \mathrm{~b}$ & $1.86 \mathrm{c}$ \\
\hline Soaking in SAA & 483.25 & 464.99 & 474.12 & $6693.6 \mathrm{a}$ & 6621.8 & $6657.7 \mathrm{a} 6136.7 \mathrm{a}$ & $2.34 \mathrm{a}$ & $2.34 \mathrm{a}$ & $2.34 \mathrm{a}$ \\
\hline Soaking in ASA & 479.46 & 468.25 & 473.86 & $6141.3 \mathrm{~b}$ & 6132.1 & $*$ & $2.15 b$ & $2.16 \mathrm{ab}$ & $2.15 b$ \\
\hline F. test & NS & NS & NS & * & NS & & $*$ & NS & $*$ \\
\hline Interaction & & & & & & * & & & \\
\hline I x S & $*$ & $*$ & * & * & $*$ & & $*$ & $*$ & $*$ \\
\hline
\end{tabular}

${ }^{1}$ Least significant difference at the $95 \%$ confidence level was used to compare means. Means of irrigation levels or seed treatments followed by the same letter are not significantly different. Columns that do not contain letters indicate no significance difference between treatments.

$2 *$ and NS indicate significance at 0.05 level of probability and non-significance of differences, respectively.

$50 \%$ ETc $(230 \mathrm{~mm}), 75 \%$ ETc $(345 \mathrm{~mm})$ and 100\% ETc $(460 \mathrm{~mm})$.

Table 9: Spike number $\mathrm{m}^{-2}$, grain yield $\left(\mathrm{kg} \mathrm{ha}^{-1}\right)$ and WUE $\left(\mathrm{kg} \mathrm{m}^{-3}\right)$ of wheat as affected by the interaction between irrigation levels and seed treatments (combined data)

Seed treatment (S) Irrigation level (I)

$50 \%$ ET $_{\mathbf{c}} \quad 75 \% \mathbf{E T}_{\mathrm{c}} \quad \mathbf{1 0 0} \% \mathrm{ET}_{\mathbf{c}}$ Spike numberm ${ }^{-2}$

\begin{tabular}{|c|c|c|c|}
\hline \multicolumn{4}{|c|}{ Spike numberm-2 } \\
\hline & B & A & A \\
\hline \multirow[t]{2}{*}{ Control } & $448.33 \mathrm{ab}$ & $481.50 \mathrm{a}$ & $480.59 b$ \\
\hline & $\mathrm{B}$ & $\mathrm{B}$ & A \\
\hline \multirow[t]{2}{*}{ Soaking in SAA } & $460.00 \mathrm{a}$ & $459.00 \mathrm{~b}$ & $503.36 \mathrm{a}$ \\
\hline & $\mathrm{C}$ & B & $\mathrm{A}$ \\
\hline \multirow[t]{3}{*}{ Soaking in ASA } & $442.00 \mathrm{~b}$ & $472.95 \mathrm{ab}$ & $506.63 a$ \\
\hline & ain yield ( $k$ & $\left.h^{-1}\right)$ & \\
\hline & $\mathrm{C}$ & B & A \\
\hline \multirow[t]{2}{*}{ Control } & $3388.9 b$ & $5412.2 b$ & $7309.4 b$ \\
\hline & $\mathrm{C}$ & B & A \\
\hline \multirow[t]{2}{*}{ Soaking in SAA } & $4696.6 \mathrm{a}$ & $6487.8 \mathrm{a}$ & $8788.8 \mathrm{a}$ \\
\hline & $\mathrm{C}$ & $\mathrm{B}$ & A \\
\hline \multirow[t]{3}{*}{ Soaking in ASA } & $4061.3 \mathrm{ab}$ & $6520.4 a$ & $7828.8 \mathrm{ab}$ \\
\hline & WUE(kg n & & \\
\hline & A & A & A \\
\hline \multirow[t]{2}{*}{ Control } & $1.78 b$ & $1.89 \mathrm{~b}$ & $1.92 b$ \\
\hline & A & A & A \\
\hline \multirow[t]{2}{*}{ Soaking in SAA } & $2.46 \mathrm{a}$ & $2.27 \mathrm{a}$ & $2.30 \mathrm{a}$ \\
\hline & A & A & A \\
\hline Soaking in ASA & $2.13 \mathrm{a}$ & $2.28 \mathrm{a}$ & $2.05 \mathrm{ab}$ \\
\hline \multicolumn{4}{|c|}{$\begin{array}{l}\text { Least significant difference at the } 95 \% \text { confidence level was used to compare } \\
\text { means. } \\
\text { Capital and small letters were used to compare between means in rows and } \\
\text { columns, respectively. }\end{array}$} \\
\hline
\end{tabular}

Such being the irrigation water level, spike number $\mathrm{m}^{-2}$, grain yield $\mathrm{ha}^{-1}$ and WUE obtained by treating seeds with SAA or ASA were statistically similar. Treating seeds with SAA significantly increased grain yieldha ${ }^{-1}$ and WUE compared to the control under all irrigation levels.

\section{Discussion}

Drought is perhaps the major factor limiting crop production worldwide (Shangguan et al. 2000). The water shortage has motivated some researchers to study deficit irrigation that maybe a feasible method contributing in enhancing agricultural system in arid region (Zhang et al.,2019). In the present study, subjecting wheat plants to deficit irrigation reducing irrigation water requirements from $100 \%$ to $75 \% \mathrm{ET}_{\mathrm{c}}$ did not cause any significant change in each of the flag leaf area, relative water content, recovery efficiency (Table 4), spike length, number of fertile spikelets spike ${ }^{-1}$, grain weight spike ${ }^{-1}$ (Table 6) and water use efficiency (Table 8). Contradictorily, each decrease in water level from $100 \%$ ETc to $75 \%$ ETc or $50 \%$ ETc was accompanied by a significant decrease in total photosynthetic pigments (Table 4), grain number spike ${ }^{-1}$ (Table 6), spike number $\mathrm{m}^{-2}$ and grain yield ha-1 (Table 8 ).

Deficit irrigation had a significant negative effect on the content of photosynthetic pigments. Lissner et al. (1999) and Farooq et al. (2013) reported that water stress causes directly or indirectly reduction in the total photosynthetic pigment content, leaf area and relative water content of wheat seedlings through molecular damage in plant cells due to the synthesis of reactive oxygen species. Results of the present research agree with previous finding that reported a significant decrease in photosynthetic pigment content and consequently the photosynthesis efficiency due to deficit irrigation such as (Kotb and Elhamahmy, 2013; Awad et al., 2015). Others found a reduction in leaf area and RWC under water stress such as (Kotb and Elhamahmy, 2013; El-Shafey 2017), which contradicts the present findings.

Schonfeld et al. (1988) revealed that RWC is a promise selection criterion for drought resistance in wheat 
and they attributed the differences in RWC values among wheat genotypes under the same drought stress level to genes variations, the genotype that are resistant to drought have more RWC. Also, the varietal differences in flag leaf area under the same water stress level were reported by Chipilski et al. (2012), which may explain the results contradiction between the present study results and the others.

Under moderate water stress and full irrigation requirements, no significant differences were observed in spike length, number of fertile spikelets spike ${ }^{-1}$ and grain weight spike $\mathrm{e}^{-1}$, but reducing irrigation level from $100 \mathrm{ET}_{\mathrm{c}}$ to $75 \% \mathrm{ET}_{\mathrm{c}}$ significantly decreased grain number spike ${ }^{-1}$ and spike number $\mathrm{m}^{-2}$. These results are in harmony with those obtained by Said and Abd El-Moneem (2016). Water stress at anthesis stage reduces pollinations and thus a smaller number of grains is formed per spike (Ashraf 1998). Farhat (2015) found that the number of spikes $\mathrm{m}^{-2}$ was the most affected trait by irrigation deficit. Under moderate water stress conditions, the compensatory capacity of the wheat plant plays an important role in the relationship between the abovementioned traits. Graziani et al. (2014) reported that, among yield components, number of grains $\mathrm{m}^{-2}$ showed the strongest correlation with grain yield. Mwadzingeni et al. (2016) pronounced that there were a moderate to high positive and significant correlations of grain yield with number of spikes plant ${ }^{-1}$, grain number spike $^{-1}$ under stressed and normal conditions. So, the grain yield ha $\mathrm{h}^{-1}$ significantly decreased with decreasing grain number spike ${ }^{-1}$ and spike number $\mathrm{m}^{-2}$ owing to reducing irrigation level from $100 \mathrm{ET}_{\mathrm{c}}$ to $75 \% \mathrm{ET}_{\mathrm{c}}$ in the present study. Kotb and Elhamahmy (2013) found that reducing irrigation water level from $100 \% \mathrm{ET}_{\mathrm{c}}$ to $80 \% \mathrm{ET}_{\mathrm{c}}$ significantly decreased grain number spike ${ }^{-1}(15.09)$, spike number $\mathrm{m}^{-2}$ (16.87\%) and grain yield ha ${ }^{-1}(14.35 \%)$ but significantly increased WUE (7.178\%). Said (2016) also reported that decreasing irrigation water level from $100 \% \mathrm{ET}_{\mathrm{c}}$ to $75 \% \mathrm{ET}_{\mathrm{c}}$ significantly decreased spike number $\mathrm{m}^{-2}$ and grain yield ha1 . The significant reduction in WUE with reducing irrigation water level from $100 \% \mathrm{ET}_{\mathrm{c}}$ to $75 \% \mathrm{ET}_{\mathrm{c}}$ was confirmed by those obtained by Sun et al. (2006) who avouched that WUE increased with increasing irrigation water from zero to full irrigation in semi-arid regions. But many investigators have reported an increased WUE of bread wheat with decreasing water amount under Mediterranean environment such as (Kotb and Elhamahmy, 2013; Mansour et al. 2017).Varietal differences in WUE under the same level of water deficit were revealed by Said and Abd ElMoneem (2016), which may explain the results contradiction between the present study results and the others.
Salicylic acid (SAA) is an endogenous plant growth hormone that promotes growth and protects the plant cells against abiotic stresses like water stress. IAA has an important role in the expression of the growth-stimulating action of SAA (Hayat and Ahmad 2007). ASA plays an important role in protecting plant cells as non- enzymatic antioxidant and regulating plant growth owing to its effect on cell division and differentiation (Price 1966).

Our findings showed that, treating seeds with SAA or ASA increased plants tolerance to drought stress demonstrated by increased total photosynthetic pigments, relative water content, recovery efficiency (Table 4), grain number spike ${ }^{-1}$ (Table 6) and grain yield ha ${ }^{-1}$ (Table 8), compared with the control.

Treating seeds with ASA significantly increased flag leaf area compared with the control. Amin et al. (2008) reported that ascorbic acid was more effective than salicylic acid in increasing the different photosynthetic pigments in wheat. Moreover, El-Shafey (2017) reported that the foliar spray of salicylic or ascorbic acid significantly increased leaf area, LAI and chlorophyll content.

Treating seeds with SAA or ASA increased plants tolerance to drought stress demonstrated by increased relative water content and recovery efficiency. Relative water content represents the plant water status and reflects the metabolic activity in tissues (Flower and Ludlow, 1986). Ritchie et al., (1990) noted that the high RWC is a drought resistant mechanism. Karimpour (2019) deduced that RWC can be used as screening tool for determining drought tolerance of genotypes in wheat. Recovery efficiency $(\mathrm{RE} \%)$, a new trait proposed in the study, is the difference between the RWC\% at sunrise of a day and the RWC\% at the sunset of the previous day. The scientific basis of the trait depends on the fact that the air usually has an extremely low water potential compared with plant or soil and there is a steep energy gradient and continual movement of water from the soil cross the plant to the air. At night, the stomata close and the transpiration is reduced to near zero. However, water continues to flow in plants until $\psi_{\text {plant }}$ would come close to equilibrium with the $\psi_{\text {soil }}$. Rates of water absorption by plants from the soil can be affected by many factors as the amount of soil moisture and $\psi_{\text {plant }}$ (Gardner et al., 1985). At night with closing the stomata and reducing the transpiration to near zero, dew is another water resource beside the soil water. Dew is one of the main water resources for plants which grow in arid and semi-arid environments due to its higher frequency and sustaining time comparing with the precipitation. It also helps the wilting plants to arrive a higher steady restoration state (Ye and Peng, 2011). Therefore, the amount of water absorbed 
at night displays the plants ability to adapt with the water stress conditions. El-Shafey (2017) revealed that the foliar application of salicylic and ascorbic acids alone or in combination, significantly increased leaf proline concentration compared with the untreated plants. High cell proline content enabled the plant to lower the water potentials. By lowering water potentials, additional water would be taken from the environment, thus buffering the immediate effect of water shortages (Abdo and Anton, 2009). El-Shafey (2017) found that the foliar application of salicylic acid or ascorbic acid significantly increased RWC of soybean leaves.

Results illustrated that spike length did not significantly change under seed treatments (Table 6). Said and Abd ElMoneem (2016) studied the response of bread wheat to foliar spray by SAA and ASA under water stress conditions; they disclosed that the spike length was increased by foliar spray at 100 ppm SAA.

Treating seeds with SAA or ASA produced at par significant increase in the number of fertile spikelets spike ${ }^{-1}$ and grain number spike ${ }^{-1}$ compared with the control. Seed soaking in ASA produced heavy grain weight spike ${ }^{-1}$ compared to the control. Generally, the results of the number of fertile spikelets spike ${ }^{-1}$, grain number spike ${ }^{-1}$, grain weight spike ${ }^{-1}$ and grain yield ha ${ }^{-1}$ take the same trend of relative water content and recovery efficiency, however treating seeds with SAA significantly increased WUE compared with the other treatments. Kotb and Elhamahmy (2013) deduced that the foliar spraying with ASA significantly increased grain number spike $^{-1}$, spike number $\mathrm{m}^{-2}$, grain yield $\mathrm{ha}^{-1}$ and WUE under stress and normal irrigation conditions. Moreover, it saved approximately 852 $\mathrm{m}^{3} \mathrm{ha}^{-1}$ of irrigation water without yield reduction compared to the control. El Sayed and Mujahed (2015) stated that soaking wheat grains in SAA before planting can be used to improve wheat productivity and WUE. In the abovementioned study of Said and Abd El-Moneem (2016) they found that the highest values of spike number $\mathrm{m}^{-2}$, grain yield $\mathrm{ha}^{-1}$ and WUE were obtained from plants sprayed with 100 ppm of ASA. El-Shafey (2017) concluded that foliar application with SAA or ASA and their combinations increased WUE for soybean plants compared with untreated plants.

Treating seeds with SAA significantly increased grain number/spike, grain yield/ha and WUE under all irrigation levels as well as RWC under severe water stress. Öztürkci and Arpali (2019) deduced that salicylic acid could be utilized as an effective growth regulator for plants in enhancing drought tolerance. Sakhabutdinova et al. (2003) attributed the protective and growth promoting effects of
SAA to the increased content of indoleacetic acid and abscisic acid (ABA), which was induced by treating wheat plants with SAA. Moreover, exogenous application of SAA improved nitrogen assimilation in wheat (Khan et al., 2013) and photosynthetic nitrogen use efficiency in mungbean (Nazar et al., 2011).

Treating seeds with SAA or ASA significantly increased flag leaf area and number of fertile spikelets spike ${ }^{-}$ 1 under full irrigation conditions. Kotb and Elhamahmy (2013) assured that foliar spray of ASA increased leaf area index and total chlorophyll content under full irrigation conditions. ASA induced 3-Bdioxgenase responsible for synthesis of plant growth promoting hormone, gibberellin (Coles et al.,1999; Kotb and Elhamahmy, 2013)

These results reflect the influence of treating seeds with drought tolerance substances such as SAA or ASA, in the concentration of $2 \mathrm{mM}$ for $8 \mathrm{~h}$ was more pronounced when plants were water stressed.

\section{Conclusion}

The impact of deficit irrigation and seed treatments on grain yield, some of its attributes and WUE of wheat cultivar "Shandaweel 1" was investigated under arid and semi-arid conditions of Egypt. Subjecting wheat plants to moderate water stress by reducing irrigation water requirements from $100 \%$ to $75 \% \mathrm{ET}_{\mathrm{c}}$ did not cause any significant change in each of the flag leaf area, relative water content, recovery efficiency, spike length, number of fertile spikelets spike ${ }^{-1}$, grain weight spike ${ }^{-1}$ and WUE, but significant decrease in total photosynthetic pigments, grain number spike ${ }^{-1}$, spike number $\mathrm{m}^{-2}$ and grain yield ha ${ }^{-1}$ were observed by reducing irrigation water requirements. Treating seeds with SAA or ASA increased plants tolerance to drought stress demonstrated by increased total photosynthetic pigments, relative water content, recovery efficiency, grain number spike ${ }^{-1}$, grain yield $\mathrm{ha}^{-1}$ and WUE compared with the control. The results indicated that treating seeds with drought tolerance substances such as SAA or ASA is a promising technique to alleviate adverse effects of water stress.

\section{References}

Abdelraouf, R., S. El Habbasha, M. Taha and K. Refaie. 2013. Effect of irrigation water requirements and fertigation levels on growth, yield and water use efficiency in wheat. Middle-East Journal of Scientific Research 16: 441-450.

Abdo, F.A. and N.A. Anton. 2009. Physiological response of sesame to soil moisture stress and potassium 
fertilization in sandy soil. Fayoum Journal of Agricultural Research and Development 23: 88-110.

Allen, R.G., L.S. Pereira, D. Raes and M. Smith. 1998. Crop evapotranspiration-Guidelines for computing crop water requirements-FAO Irrigation and drainage paper 56. Fao, Rome 300: D05109.

Amin, A., E.S.M. Rashad and F.A. Gharib. 2008. Changes in morphological, physiological and reproductive characters of wheat plants as affected by foliar application with salicylic acid and ascorbic acid. Australian Journal of Basic and Applied Sciences 2: 252-261.

Ashraf, M.Y. 1998. Yield and yield components response of wheat (Triticum aestivum L.) genotypes grown under different soil water deficit conditions. Acta Agronomica Hungarica 46: 45-51.

Attia, A., N. Rajan, G. Ritchie, S. Cui, A. Ibrahim, D. Hays, Q. Xue and J. Wilborn. 2015. Yield, quality, and spectral reflectance responses of cotton under subsurface drip irrigation. Agronomy Journal 107: 1355-1364.

Awad, A., H. Abdel-Mottaleb, M. Hammada, M. Kotb and M. Abass. 2015. Effect of drought stress conditions and nitrogen fertilizer on growth of two cultivars of wheat (Triticum aestivum L.). Journal of Plant Production Sciences; Suez Canal University 3: 9-17.

Barrs, H. and P. Weatherley. 1962. A re-examination of the relative turgidity technique for estimating water deficits in leaves. Australian Journal of Biological Sciences 15: 413-428.

Bilalis, D., A. Karkanis, A. Efthimiadou, A. Konstantas and V. Triantafyllidis. 2009. Effects of irrigation system and green manure on yield and nicotine content of Virginia (flue-cured) Organic tobacco (Nicotiana tabaccum), under Mediterranean conditions. Industrial Crops and Products 29: 388-394.

Chipilski, R.R., K.V. Kocheva, V.R. Nenova and G.I. Georgiev. 2012. Physiological responses of two wheat cultivars to soil drought. Zeitschrift für Naturforschung C 67: 181-186.

Coles, J.P., A.L. Phillips, S.J. Croker, R. García-Lepe, M.J. Lewis and P. Hedden. 1999. Modification of gibberellin production and plant development in Arabidopsis by sense and antisense expression of gibberellin 20-oxidase genes. The Plant Journal 17: 547-556.

Ding, P. and Y. Ding. 2020. Stories of salicylic acid: A plant defense hormone. Trends in Plant Science. In press.

Duncan, D.B. 1955. Multiple range and multiple F tests. Biometrics 11: 1-42.
El Sayed, H.E.S.A. and H.M. Mujahed. 2015. Exogenous application of salicylic acid for stimulates germination, growth and yield production of wheat (Triticum aestivum L.) plant under Water Stress. International Journal of Life Sciences 5: 88-104.

El Tayeb, M.A. and N.L. Ahmed. 2010. Response of wheat cultivars to drought and salicylic acid. AmericanEurasian Journal of Agronomy 3: 1-7.

El-Shafey, A.I. 2017. Response of soybean to water stress conditions and foliar application with salicylic and ascorbic acids. Zagazig Journal of Agricultural Research 44: 1-22.

Fahad, S., A.A. Bajwa, U. Nazir, S.A. Anjum, A. Farooq, A. Zohaib, S. Sadia, W. Nasim, S. Adkins, S. Saud and M.Z. Ihsan. 2017. Crop production under drought and heat stress: Plant responses and management options. Frontiers in Plant Science 8: 1147.

Farhat, W. 2015. Response of 21 spring bread wheat genotypes to normal and reduced irrigation in north delta. Journal of Plant Production 6: 943-963.

Farooq, M., M. Irfan, T. Aziz, I. Ahmad and S. Cheema. 2013. Seed priming with ascorbic acid improves drought resistance of wheat. Journal of Agronomy and Crop Science 199: 12-22.

Flower, D. and M. Ludlow. 1986. Contribution of osmotic adjustment to the dehydration tolerance of water-stressed pigeon pea (Cajanus cajan (L.) millsp.) leaves. Plant, Cell \& Environment 9: 33-40.

Gardner, F., R. Pearce and R. Mitcell. 1985. Physiology of crop plants: Ames: Iowa state university Press.

Gomez, K.A. and A.A. Gomez. 1984. Statistical Procedures for Agricultural Research. John Wiley \& Sons. United States of America. 680 p.

Graziani, M., M. Maccaferri, C. Royo, F. Salvatorelli and R. Tuberosa. 2014. QTL dissection of yield components and morpho-physiological traits in a durum wheat elite population tested in contrasting thermo-pluviometric conditions. Crop and Pasture Science 65: 80-95.

Hayat, S. and A. Ahmad. 2007. Salicylic acid-a plant hormone. Springer Science \& Business Media. Dordrecht, The Netherlands. $410 \mathrm{p}$

Hoerling, M., J. Eischeid, J. Perlwitz, X. Quan, T. Zhang and P. Pegion. 2012. On the increased frequency of Mediterranean drought. Journal of Climate 25: 21462161.

Ishikawa, T., K. Takahara, T. Hirabayashi, H. Matsumura, S. Fujisawa, R. Terauchi, H. Uchimiya and M. KawaiYamada. 2009. Metabolome analysis of response to oxidative stress in rice suspension cells overexpressing cell death suppressor Bax inhibitor-1. Plant and Cell Physiology 51: 9-20. 
James, L.G. 1988. Principles of Farm Irrigation Systems Design. John Wiley and Sons Limited. Chichester, United Kingdom. 543 p.

Karimpour, M. 2019. Effect of drought stress on RWC and chlorophyll content on wheat (Triticum durum L.) genotypes. World Essays Journal 7:52-56.

Khan, M.I.R., N. Iqbal, A. Masood, T.S. Per and N.A. Khan. 2013. Salicylic acid alleviates adverse effects of heat stress on photosynthesis through changes in proline production and ethylene formation. Plant Signaling \& Behavior 8: e26374.

Khan, W., B. Prithiviraj and D.L. Smith. 2003. Photosynthetic responses of corn and soybean to foliar application of salicylates. Journal of plant physiology 160: 485-492.

Kotb, M.A. and M.A.M. Elhamahmy. 2013. Foilar application of ascorbic acid improved drought tolerance and productivity of wheat (Triticum aestivum L.). Journal of Plant Production Sciences; Suez Canal University 1: 1-16.

Lissner, J., H.H. Schierup, F.A. Comín and V. Astorga. 1999. Effect of climate on the salt tolerance of two Phragmites australis populations.: I. Growth, inorganic solutes, nitrogen relations and osmoregulation. Aquatic Botany 64: 317-333.

Mansour, E., M.I. Abdul-Hamid, M.T. Yasin, N. Qabil and A. Attia. 2017. Identifying drought-tolerant genotypes of barley and their responses to various irrigation levels in a Mediterranean environment. Agricultural Water Management 194: 58-67.

Mstat, C. 1989. Mstat-C Software, Version 1.4. Crop and Soil Science Department, Michigan State University, East Lancing, MI.

Mwadzingeni, L., H. Shimelis, S. Tesfay and T.J. Tsilo. 2016. Screening of bread wheat genotypes for drought tolerance using phenotypic and proline analyses. Frontiers in Plant Science 7: 1276.

Nazar, R., N. Iqbal, S. Syeed and N.A. Khan. 2011. Salicylic acid alleviates decreases in photosynthesis under salt stress by enhancing nitrogen and sulfur assimilation and antioxidant metabolism differentially in two mungbean cultivars. Journal of Plant Physiology 168: 807-815.

Ouda, S., K.A. El-Latif and F. Khalil. 2016. Water requirements for major crops. Major crops and water scarcity in Egypt. Switzerland. Springer. p. 25-32.

Öztürkci, Y. and D. Arpali. 2019. The effects of salicylic acid on the growth and some physiological properties of bread wheat varieties under drought stress. I I $d ı r$ Üniversitesi Fen Bilimleri Enstitüsü Dergisi 9: 17371746.
Price, C. 1966. Ascorbate stimulation of RNA synthesis. Nature 212: 1481-1481.

Ritchie, S.W., H.T. Nguyen and A.S. Holaday. 1990. Leaf water content and gas-exchange parameters of two wheat genotypes differing in drought resistance. Crop Science 30: 105-111.

Robredo, A., U. Pérez-López, H.S. de la Maza, B. González-Moro, M. Lacuesta, A. Mena-Petite and A. Munoz-Rueda. 2007. Elevated $\mathrm{CO}_{2}$ alleviates the impact of drought on barley improving water status by lowering stomatal conductance and delaying its effects on photosynthesis. Environmental and Experimental Botany 59: 252-263.

Said, M.T. 2016. Productivity of bread wheat under different irrigation levels and splitting nitrogen fertilization in newly reclaimed soils. Journal of Plant Production,Mansoura University 7: 1007-1012.

Said, M.T. and A.M.A. Abd El-Moneem. 2016. Response of Two Bread Wheat Cultivars to Foliar Spray by Salicylic and Ascorbic Acids under Water Stress Conditions. Assiut Journal of Agricultural Sciences 47:391-404.

Sakhabutdinova, A., D. Fatkhutdinova, M. Bezrukova and F. Shakirova. 2003. Salicylic acid prevents the damaging action of stress factors on wheat plants. Bulgarian Journal of Plant Physiology 21: 314-319.

Schonfeld, M.A., R.C. Johnson, B.F. Carver and D.W. Mornhinweg. 1988. Water relations in winter wheat as drought resistance indicators. Crop Science 28: 526531.

Shangguan, Z., M. Shao and J. Dyckmans. 2000. Effects of nitrogen nutrition and water deficit on net photosynthetic rate and chlorophyll fluorescence in winter wheat. Journal of Plant Physiology 156: 46-51.

Smakhtin, V., C. Revenga and P. Döll. 2004. A pilot global assessment of environmental water requirements and scarcity. Water International 29: 307-317.

Smirnoff, N. 2000. Ascorbate biosynthesis and function in photoprotection. Philosophical Transactions of the Royal Society of London. SERIES B: Biological Sciences 355: 1455-1464.

Steel, R.G.D., J.H. Torrie and D.A. Diskey. 1997. Principles and Procedures of Statistics: A Biomedical Approach. $3^{\text {rd }}$ Ed. McGraw-Hill Book Co., New York. $666 \mathrm{p}$

Sun, H.Y., C.M. Liu, X.Y. Zhang, Y.J. Shen and Y.Q. Zhang. 2006. Effects of irrigation on water balance, yield and WUE of winter wheat in the North China Plain. Agricultural Water Management 85: 211-218.

Voldeng, H. and G. Simpson. 1967. The relationship between photosynthetic area and grain yield per plant 
in wheat. Canadian Journal of Plant Science 47: 359365.

Ye, Y. and S. Peng. 2011. Review of dew action effect on plants. Shengtai Xuebao/Acta Ecologica Sinica 31: 3190-3196.

Zhang, H. and T. Oweis. 1999. Water-yield relations and optimal irrigation scheduling of wheat in the Mediterranean region. Agricultural Water Management 38: 195-211.
Zhang, H., M. Han, L.H. Comas, K.C. DeJonge, S.M. Gleason, T.J. Trout and L. Ma. 2019. Response of maize yield components to growth stage-based deficit irrigation. Agronomy Journal 3:1-9.

Zhu, J.K. 2000. Genetic analysis of plant salt tolerance using Arabidopsis. Plant Physiology 124: 941-948. 